\title{
Cephaleuros parasiticus, associated with algal spot disease on Psidium guajava in Thailand
}

\author{
Anurag Sunpapao ${ }^{1} \cdot$ Narasinee Thithuan $^{1} \cdot$ Penpadsorn Bunjongsiri $^{1} \cdot$ Siwaret Arikit $^{2,3}$
}

Received: 4 December 2015 / Accepted: 7 April 2016 /Published online: 11 April 2016

(C) Australasian Plant Pathology Society Inc. 2016

\begin{abstract}
During 2014-2015, algal spot disease was noticed in the guava orchards of northern and southern Thailand. Symptoms of the disease occurred on the leaves and fruit. Scabs were formed on heavily infected fruits. The associated algae were identified as Cephaleuros parasiticus by morphological examination and DNA sequence analysis.
\end{abstract}

Keywords Green algae · Trentepoliales · Guava ·

Morphology $\cdot$ Parasite

Cephaleuros is a genus of green algae (Chlorphyta) in the order Trentepohliales, family Trentepohliaceae. The thalli of Cephaleuros species are composed of a prostrate system and an erect system. The prostrate system consists of compact filamentous cells that form the thallus and gametangia, whereas sporangiophores and setae are included in the erect system. The filamentous cells of Cephaleuros penetrate the cuticle of the plant host and usually colonize the area between the cuticle and epidermal cells. Some Cephaleuros species grown intercellularly between plant cells of the epidermis and palisade parenchyma and into the mesophyll. The growth of

Anurag Sunpapao

anurag.su@psu.ac.th

1 Department of Pest Management, Faculty of Natural Resources, Prince of Songkla University, Hatyai, Songkhla 90112, Thailand

2 Department of Agronomy, Faculty of Agriculture at Kamphaeng Saen and Rice Science Center, Kasetsart University, Nakhon Pathom 73140, Thailand

3 Rice Gene Discovery, National Center for Genetic Engineering and Biotechnology (BIOTEC), National Science and Technology Development Agency (NSTDA), Kasetsart University, 73140 Kamphaeng Saen, Nakhon Pathom, Thailand
Cephaleuros species causes necrosis in the tissues beneath its thallus. The necrotic tissues on leaf or stem surfaces of a host plant are visible symptoms of the disease referred to as "algal spot".

Guava (Psidium guajava) is a medium-to-large-sized perennial fruit tree in the family Myrtaceae. Guava orchards are commonly found in tropical and subtropical areas of Southeast Asia and is cultivated in all parts of Thailand, ranging from North to South. However, the guava plantations are facing several diseases due to the long annual period of high rainfall and high temperatures (Misra 2004). The most severe pathogens that cause devastating damage on the guava are plant parasitic algae in the genus Cephaleuros (Marlatt and Campbell 1980).

Algal spot was noticed in guava orchards in different ecological zones of southern Songkhla province and northern Phrae province, Thailand. Small lesions developed on both the upper and the lower leaf surfaces and expand with the growth of the algal thallus. Lesions usually became brownish purple late in their development (Fig.1A: a). Tufts of sporangiophores growing from brown, necrotic tissue were mostly observed on the lower leaf surfaces of guava leaves (Fig.1A: b and c). The dark brown lesions with tufts of sporangiophores were also observed on the fruit, (Fig.1A: d-f), with scabs developing in severe infections (Fig. 1A: g).

Symptomatic leaf samples $(n=30)$ were collected from each guava orchard and brought to the laboratory for diagnosis. Filamentous cells of the algae were highly irregular making size measurement difficult (Fig. 1B: a). Gametangia were beneath the cuticle, solitary or in clusters, ovoid to ellipsoid in shape with $27.5-40 \times 12.5-27.5 \mu \mathrm{m}($ mean $=32.58$, $21.16 \mu \mathrm{m})$ (Fig. 1B: b). Sporangiophores projected through the cuticle of the upper and lower leaf surfaces 4-7 cells, $232.5-490 \times 10-22.5 \mu \mathrm{m}($ mean $=335.63,12.75 \mu \mathrm{m})$ with radiating sporangiate-laterals (crooked suffultory cells 


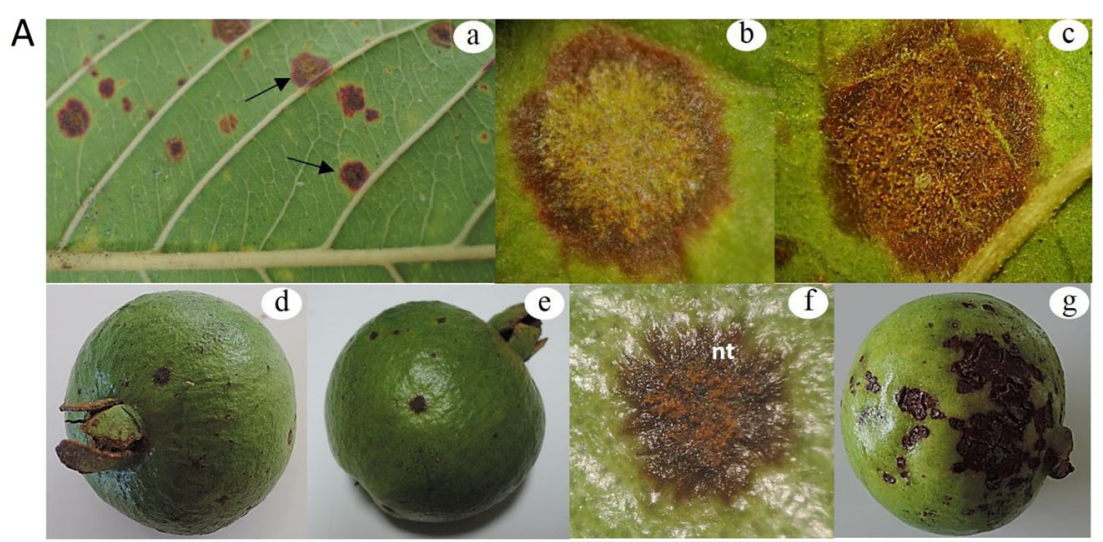

B

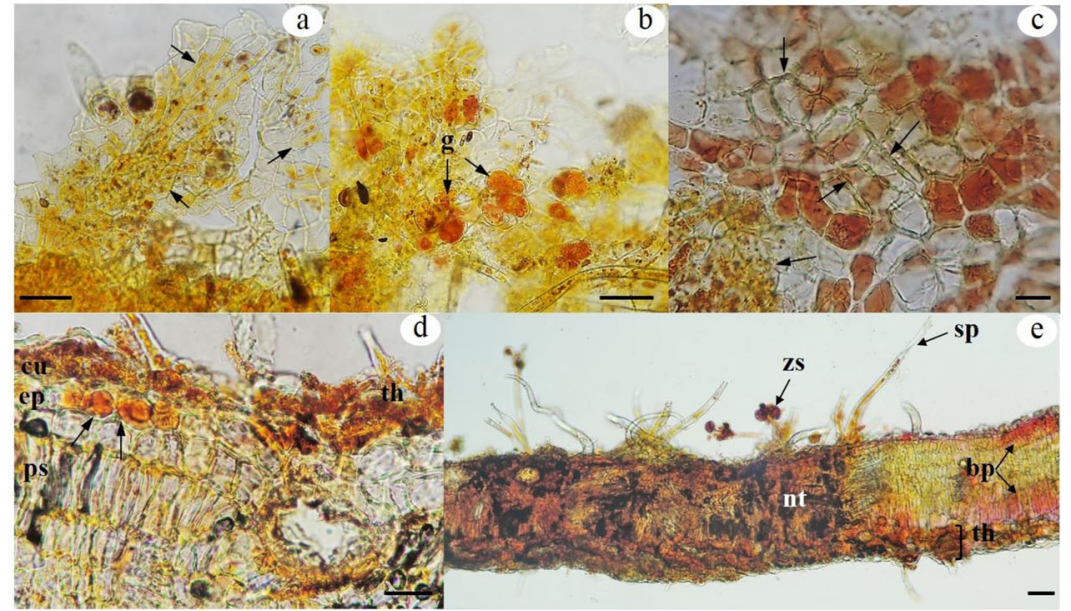

Fig. 1 a: Lesions caused by Cephaleuros parasiticus on Psidium guajava; (a)-brownish purple lesions surrounded by yellow halos on a lower leaf surface; $(b)$ - tufts of sporangiophores projecting from necrotic tissues of the upper leaf surface; $(c)$ - tufts of sporangiophores projecting from necrotic tissue of the lower leaf surface; $(d \& e)$ lesions on fruit; $(f)$ - tufts of sporangiophores with necrotic tissue (nt) on fruit; $(g$ ) - heavily infected fruit. b: Morphological characteristics of $C$. parasiticus. (a)-irregular shape filamentous cells, (arrows); (b) - clusters of gametangia $(\mathrm{g}) ;(c)$ - vertical section through a lesion showing algal filaments (arrows) growing among host plant cells; (d) transverse section of a lesion showing subepidermal growth below the upper leaf surface, and gametangia forming beneath cuticle (arrows), cuticle (cu), epidermis (ep), palisade (ps), thallus (th); $(e)$ - Transverse section of a guava leaf showing full-thickness necrosis, sporangiophores (sp), zoosporangia (zs), thallus (th), and brownish purple (bp) tissues. The scale bars represent: $a-c, 50 \mu \mathrm{m} ; d-e, 100 \mu \mathrm{m}$
Fig. 2 Neighbour-joining tree generated using sequences of the 18S rDNA sequences of Cephaleuros parasiticus PSUG01 and other green algae (Trentepohliaceae, Chlorophyta). The bootstrap values are shown on the branches and the GenBank accession numbers are shown in parentheses

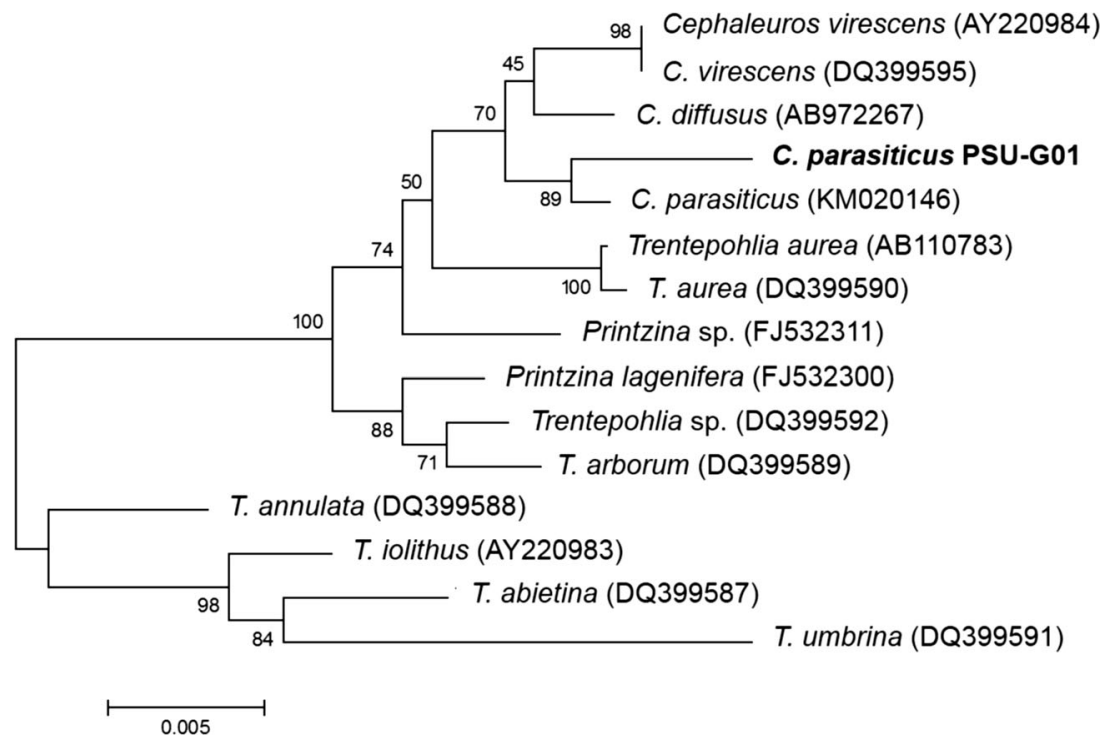


attached to zoosporangia). Sporangia were globular to ovoid with $20-30 \times 15-25 \mu \mathrm{m}$ (mean $=25.08,18.83 \mu \mathrm{m})$. Erect sterile filaments (setae) were rarely produced, and then apparently predominantly through the upper epidermis. Longitudinal leaf sections showed algal filaments growing among the parenchyma and mesophyll cells (Fig. 1B: c). Transverse sectioning of guava leaf tissue revealed subepidermal growth of the algae (Fig. 1B: d). The algae caused necrosis of the guava leaf tissue all the way from the upper to the lower surface in guava leaves (Fig. 1B: e). Based on the monograph by Thompson and Wujek (1997) the algae were identified as Cephaleuros parasiticus.

DNA-based identification of different groups of algae using encoding genes has been very successful. The $18 \mathrm{~S}$ small subunit ribosomal DNA and chloroplast-encoded ribulose-1, 5-bisphosphate carboxylase/oxygenase large $(r b c \mathrm{~L})$ subunit are common genes for identification. These genes are considered an excellent tool for phylogenetic inference among the green algae (Chapman and Buchheim 1991; Hamby and Zimmer 1992). To confirm the genus Cephaleuros for these algae, PCR amplification and nucleotide sequencing were conducted. The algae were cultured on Bold's basal media (BBM) (Bischoff and Bold 1963; Andersen 2005). Filamentous colonies were harvested and the DNA extracted using the CTAB method (Doyle and Doyle 1987; Doyle and Dickson 1987; Cullings 1992). Portions of 18 S rRNA were amplified by PCR using the PNS1 and NS41 primer pair (Hibbet 1996). The partial nucleotide sequence was 1113 bases long. The $18 \mathrm{~s}$ rDNA sequence was compared to known Cephaleuros spp. and other genera in the NCBI (the National Center for Biotechnology Information) database using the BLAST search function. The sequence for the Thailand Cephaleuros parasiticus strain was deposited in GenBank database with accession number LC104282. According to the phylogenetic relationship derived from the neighbor-joining analysis with selected sequences imported from NCBI indicated that the Thailand isolate PSU-G01 clustered with a sequence of Cephaleuros parasiticus, well separated from other species (Fig. 2). The phylogenetic relationships of $18 \mathrm{~s}$ rDNA has been used to identified Cephaleuros species in Thailand (Pitaloka et al. 2015; Sunpapao and Pitaloka 2015; Sunpapao et al. 2015, 2016).

An earlier study of algal spot in Thailand (Visarntanon $2010)$ stated that $C$. virescens was responsible for most infections. Recently, Pitaloka et al. (2014) identified C. solutus as a causal organism of algal spot in Thailand and may have been the first in this country to characterize the algal pathogen by morphology, using the Thompson and Wujek (1997) monograph. Since then six species of Cephaleuros have been identified on hosts in southern Thailand: C. expansa, C. diffusus, C. karstenii, C. pilosa, C. solutus and C. virescens (Pitaloka et al. 2014, 2015; Sunpapao and Pitaloka 2015; Sunpapao et al. 2015, 2016).
A prior report by Sunpapao et al. (2015) described algal thalli on guava hosts in southern Thailand expanding radially, and identified the causal agent as $C$. expansa. We collected specimens from both southern and northern Thailand, and the filamentous thallus cells of $C$. parasiticus were different from those in the previous report. The subepidermal growth habit, intercellular spread of the filamentous cells, sporangiophores protruding through lower leaf surfaces, and head cells with radiating sporangiate-laterals (crooked suffultory cells attached to zoosporangia) distinguished $C$. parasiticus from the other species of the genus identified in Thailand. However, the steps to confirm Cephaleuros as a pathogen (Koch's postulate) have not been completed because zoospores could not be produced on synthetic media for inoculation (Chapman and Good 1983; Holcomb et al. 1998; Suto and Ohtani 2011). Algal specimens from our study were deposited in the culture collection of the Department of Pest Management, Faculty of Natural Resources, Prince of Songkla University, Thailand with accession number PSUPMPG1501. To our knowledge, this is the first report of $C$. parasiticus on guava in Thailand.

Acknowledgments The authors would like to thank the Center of Excellence in Agricultural and Natural Resources Biotechnology (CoEANRB): phase 2, Faculty of Natural Resources, Prince of Songkla University, for funding and facilities. The copy-editing service of RDO/ PSU and the helpful comments of Dr. Seppo Karrila are gratefully acknowledged.

\section{References}

Andersen RA (2005) Algal culturing techniques. Elsvier Academic Press, Amsterdam

Bischoff HW, Bold HC (1963) Phycological studies. IV. Some soil algae from enhanted rock and related algal species. University of Texas Publication, Dallas

Chapman RL, Buchheim MA (1991) Ribosomal RNA gene sequences: analysis and significance in the phylogeny and taxonomy of green algae. Crit Rev Plant Sci 10:343-368

Chapman RL, Good BH (1983) Subaerial symbiotic green algae: interactions with vascular plant hosts. In: Goff LJ (ed) Algal symbiosis: a continuum of interaction strategies. Cambridge University Press, Cambridge, pp 173-204

Cullings KW (1992) Design and testing of a plant-specific PCR primer for ecological and evolutionary studies. Mol Ecol 1:233-240

Doyle JJ, Dickson EE (1987) Preservation of plant samples for DNA restriction endonuclease analysis. Taxon 36:715-722

Doyle JJ, Doyle JL (1987) A rapid DNA isolation procedure for small quantities of fresh leaf tissue. Phytochem Bull 19:11-15

Hamby RK, Zimmer EA (1992) Ribosomal RNA as a phylogenetic tool in plant systematics. In: Soltis PS, Soltis DE, Doyle JJ (eds) Molecular systematics of plants. Chapman and Hall, New York, pp 50-91

Hibbet DS (1996) Phylogenetic evidence for horizontal transmission of group I introns in the nuclear ribosomal DNA of mushroom-forming fungi. Mol Biol Evol 13:903-917

Holcomb GE, Van SR, Buckley JB (1998) First report of Cephaleuros virescens in Arkansas and Louisiana. Plant Dis 82:263 
Marlatt RB, Campbell CW (1980) Incidence of algal disease (Cephaleuros sp.) in selections of guava (Psidium guajava). Proc Fla State Hort Soc 93:109-110

Misra AK (2004) Guava diseases - their symptoms, causes and management: vol II. In: Naqvi SAMH (ed) Diseases of fruits and vegetables. Kluwer Academic Publishers, Springer Netherlands, pp 81-119

Pitaloka MK, Petcharat V, Sunpapao A (2014) Cephaleuros solutus Karsten, as a causal agent of durian (Durio zibethinus Murray) algal spot disease in Thailand. Khon Kaen Agric J 42(Suppl 3):644-648

Pitaloka MK, Petcharat V, Arikit S, Sunpapao A (2015) Cephaleuros virescens, the cause of an algal leaf spot on Para rubber in Thailand. Aust Plant Dis Notes 10:1-4

Sunpapao A, Pitaloka MK (2015) A new record of plant parasitic green algae, Cephaleuros diffusus (Trentepohliaceae, Chlorophyta), on Acacia auriculiformis hosts in Thailand. Biodiversitas 16(2):116 120
Sunpapao A, Pitaloka MK, Arikit S (2015) The genus Cephaleuros Kunze ex E.M.Fries (Trentepohliales, Ulvophyceae) from southern Thailand. Nova Hedwigia 101(3-4):451-462

Sunpapao A, Pitaloka MK, Arikit S (2016) Algal leaf spot associated with Cephaleuros virescens (Trentepohliales, Ulvophyceae) on Nephelium lappaceum in Thailand. Biodiversitas 17(1):31-35

Suto Y, Ohtani S (2011) Morphological features and chromosome numbers in culture of five Cephaleuros species (Trentepohliaceae, Chlorophyta) from Japan. Phycol Res 59:42-51

Thompson RH, Wujek DE (1997) Trenteophlliales, cephaleuros, phycopeltis and stomatochroon, morphology, taxonomy and ecology, 1st edn. Enfield Publishing and Distribution, United State of America, p 149

Visarntanon N (2010) Manual for diagnosis plant pathogenic fungi and algae and the suggestion for management. 2nd. Kasetsart University Press, Bangkok, p 594 (in Thai) 